\title{
Europos socialinių mokslų duomenų archyvų konsorciumas CESSDA ERIC: kuriant ir skatinat empirinių tyrimų duomenų atvirumą
}

\author{
Vaidas Morkevičius, Giedrius Žvaliauskas \\ Kauno technologijos universitetas \\ A. Mickevičiaus g. 37, LT-44244 Kaunas
}

Šiuolaikiniai socialiniai mokslai išgyvena tam tikrą transformaciją tapdami vis labiau priklausomi nuo empirinių duomenų analizès, o teorijų vystymas vis plačiau grindžiamas empiriniais įrodymais. Dažnai tik ilgalaikiai ir tarptautiniai palyginamieji tyrimai gali atsakyti i teoriniuose veikaluose keliamus klausimus ir formuluojamas hipotezes, todėl vis reikalingesni yra duomenu ištekliai, kuriuose žmonių požiūriai, savijautos ir elgsenos būtų tiriami ilgą laiką ir skirtingose šalyse.

Tuo pačiu viena iš šiuolaikinio mokslo politikos nuostatų numato, kad empirinių tyrimų metu surinkti duomenys turi būti kaupiami duomenų archyvuose, kur taptų pasiekiami kitiems mokslininkams ir tyrëjams bei visuomenei. Stebint šiuo metu itin aktyvią europinių atvirosios prieigos iniciatyvų plètrą ${ }^{1}$, akivaizdu, kad empirinių tyrimų duomenų atvirumas kitiems tyrejjams ir mokslininkams tampa vis svarbesnis, nes taip puoselèjami dalijimosi surinktais duomenimis kultūros principai, užtikrinamas ilgalaikis už viešus finansinius išteklius sukurtų empirinių tyrimų duomenų saugojimas, išvengiant duomenų tyčinio ar netyčinio praradimo, sukuriama galimybė kitiems mokslininkams ir tyrëjams rasti bei pakartotinai naudoti jau esamus duomenų šaltinius, atlikti antrinę jų analizę. Todèl socialinių mokslų duomenų archyvų kūrimasis ir jų teikiamų paslaugų plètra yra šių bendrų mokslo raidos tendencijų atspindys, nes socialinių mokslų duomenų archyvai užtikrina mokslininkams nemokamą prieigą prie svarbių nacionalinių ir tarptautinių tyrimų duomenų išteklių.

Europoje veikiančių nacionalinių socialinių mokslų archyvų veiklos pagrindas ženkliai pasikeite, kai 2017 m. birželio 14 d. buvo ịsteigtas Europos mokslinių tyrimų infrastruktūros konsorciumo statusą turintis Europos socialinių mokslų duomenų archyvų konsorciumas (angl. Consortium of European Social Science Data Archives - European Research Infrastructure Consortium, CESSDA ERIC). CESSDA ERIC pirmtakè yra Europos socialinių mokslų duomenų archyvų taryba (angl. Council of European Social Science Data Archives), 1976 m. ịkurta skètiné organizacija, vienijusi keliasdešimties Europos šalių socialinių mokslų duomenų archyvus. Tarybos tikslas buvo kaupti ir saugoti empirinių tyrimų duomenis bei kurti prieigą tyrèjams ir studentams prie kiekybinių socialinių tyrimų duomenų, skirtų antrinei analizei ${ }^{2}$. Europos socialinių mokslų duomenų archyvų tarybos vienijami archyvai teikè prieigą prie daugiau nei 50000 empirinių duomenų rinkinių bei skatino duomenų mainus tarp skirtingų organizacijų. Nuo $2006 \mathrm{~m}$. CESSDA buvo reguliariai ịtraukiama į Europos mokslinių tyrimų infrastruktūrų strategijos forumo (angl. European Strategy Forum on Research Infrastructures, ESFRI) kelrodị, o 2016 m. ESFRI kelrodyje jai suteiktas Gairiu (angl. Landmark) statusas. Šis statusas suteikiamas infrastruktūroms, kurios buvo kuriamos vadovaujantis ESFRI kelrodžiu ir šiuo metu sudaro pagrindą Europos mokslinių tyrimų erdvės konkurencingumui, ir kurioms ES numačiusi tolesnę paramą ir investicijas. Galiausiai, $2017 \mathrm{~m}$. vasarą CESSDA tapo Europos mokslinių tyrimų infrastruktūros konsorciumu - CESSDA ERIC, kuriam 2019 m. priklausè 18 šalių ${ }^{3}$.

\footnotetext{
${ }_{1}^{1}$ Žr. plačiau www.eosc-portal.eu, http://data.europa.eu/euodp/en/home, www.europeandataportal.eu ir kt.

${ }^{2}$ Plačiau apie CESSDA istoriją žr. https://www.cessda.eu/About/History.

${ }^{3}$ Tikrosios šalys narès yra Austrija, Belgija, Čekijos Respublika, Danija, Suomija, Prancūzija, Vokietija, Graikija, Vengrija, Nyderlandai, Norvegija, Portugalija, Serbija, Slovakija, Slovenija, Švedija, Jungtinė Karalystė bei Šveicarija turinti stebètojo statusą.
} 
CESSDA ERIC vizija ${ }^{4}$ - sukurti tvarią tyrimų infrastruktūrą, leidžiančią mokslo bendruomenei atlikti aukštos kokybès socialinių mokslų tyrimus, padedančius efektyviai spręsti svarbiausius iššūkius, su kuriais šiandien susiduria visuomenė bei palengvinančius socialinių mokslų mokymą ir mokymąsi - remiasi ịsitikinimu, kad prieigos prie socialinių mokslų duomenų ir metaduomenų užtikrinimas yra gyvybiškai svarbus uždavinys tiek mokslui, tiek visuomenei. Todèl CESSDA ERIC pagrindinis tikslas yra teikti paslaugas mokslinių duomenų kūrèjams, kad jie galètų lengvai aprašyti ir išsaugoti savo duomenis, jei reikia - saugioje terpejje.

CESSDA ERIC kuria ir tobulina duomenų kūrimo, aprašymo ir metaduomenų standartus, duomenų kuravimo (angl. data curation) standartus, paslaugas ir irankius bei teikia vieningą centralizuotą prieigą prie Europos šalių duomenų archyvuose saugomų duomenų ${ }^{5}$ CESSDA ERIC veiklose siekiama kuo griežčiau laikytis „FAIR“ (angl. Findable, Accessible, Interoperable, Reusable) duomenų kuravimo principų, kad mokslininkų sukuriami duomenys būtų randami ir pateikiami su informacija, kas tai per duomenys, kur jie saugomi ir kaip gauti prieigą prie jų.

Kitas svarbus CESSDA ERIC uždavinys - ugdyti duomenų kultūrą ir duomenų naudojimą vykdant duomenų paieškos, duomenų valdymo ir duomenų analizès mokymus. Pvz., 2018 m. gegužès 29 d. Čekijos Mokslų akademijos Sociologijos institute vyko CESSDA ERIC seminaras „Duomenu Europoje apžvalga: europiečių požiūriai ir vertybès“ (angl. Exploring Data in Europe - with a Focus on European Attitudes and Values), kuriame Jen Buckley iš Jungtinès Karalystès Duomenų tarnybos ir Martin Vavra iš Čekijos socialinių mokslų duomenų archyvo seminaro dalyvius supažindino su svarbiausiais duomenų ištekliais Europos socialinių mokslų duomenų archyvuose bei teikè praktinius patarimus, kaip rasti aukštos kokybės duomenis. Be to, Čekijos Respublikos Mokslų akademijos Sociologijos instituto mokslininkès Kristýna Bašná, Yana Leontiyeva ir Klára Plecitá dalinosi savo patirtimi atliekant mokslinius tyrimus nacionalizmo, politinès kultūros bei migracijos temomis ${ }^{6}$.

Vienas iš CESSDA ERIC renginių mokslinių duomenų valdymo tema vyko ir Kaune, kai 2018 m. spalio 18 d. KTU Socialinių, humanitarinių mokslų ir menų fakulteto Duomenų analizės ir archyvavimo (DAtA) centras ir Lietuvos HSM duomenu archyvas (LiDA) surengè seminarą „Socialinių tyrimų duomenų valdymas: europinė perspektyva“ (angl. Social Research Data Management: European Perspectives). Seminaras organizuotas bendradarbiaujant su CESSDA ERIC, o jo metu paskaitas apie socialinių tyrimų duomenų valdymą vedè lektore Alexandra Stam iš Šveicarijos socialinių duomenų fondo (angl. Swiss Foundation for Research in Social Sciences, FORS). "OpenAIRE“" projekto atstovė Ieva Cesevičiūtė pasakojo apie mokslinių duomenų valdymo plano rengimą. Taip pat paskaitas bei praktines užduotis vedè DAtA centro darbuotojai Audronė Telešienè, Rimantas Rauleckas ir Vaidas Morkevičius.

Taigi, apibendrinant galima teigti, kad CESSDA ERIC yra socialinių mokslų duomenų infrastruktūra, jungianti Europos socialinių mokslų duomenų archyvus ir siekianti sudaryti kuo palankesnes sąlygas vykdyti aukštos kokybès nacionalinius bei tarptautinius tyrimus. CESSDA ERIC stiprina Europos mokslininkų ir tyrejų integraciją i tarptautinę duomenų vartotojų bendruomenę bei teikia platformą duomenimis grịstam inovacijų ir sprendimų vystymui, taigi veikia kaip katalizatorius, lengvinantis mokslinių duomenų naudojimą ekonominių, socialinių ir kt. naudų kūrimui. Taip ji skatina aukščiausios kokybès ir tarptautinès svarbos socialinių mokslų srities tyrimus, sudaro geresnes galimybes formuoti ir igyvendinti duomenimis grịstas nacionalinès politikos programas bei stiprina žmogiškajji potencialą per mokslininkų ir praktikų metodologinių kompetencijų kèlimą ir duomenų kultūros puoselëjimą. Lietuvos ịsijungimas į CESSDA ERIC sustiprintų Lietuvos mokslininkų ir tyrejjų integraciją į tarptautinę duomenų vartotojų bendruomenę. Taip pat tokio žingsnio naudos gavejais būtų valstybès institucijų politikos formuotojai ir igyvendintojai, siekiantys priimti duomenimis grịstus sprendimus; žurnalistai ir kiti komunikacijos

\footnotetext{
${ }^{4}$ Žr. www.cessda.eu/About/Mission-Vision.

${ }^{5}$ CESSDA ERIC katalogas https://datacatalogue.cessda.eu.

${ }^{6}$ Visa seminaro medžiaga prieinama CESSDA ERIC portale: www.cessda.eu/Training/Event-Calendar/CESSDA-

Workshop-Exploring-Data-in-Europe-with-a-Focus-on-European-Attitudes-and-Values.
} 
specialistai, kurių veikloms reikia duomenų; socialinių tyrimų bendrovės, laisvai samdomi tyrèjai bei politikos analitikai. 